\title{
Corrigendum: Knock-Down of the Phosphoserine Phosphatase Gene Effects Rather N- Than S-Metabolism in Arabidopsis thaliana
}

\author{
Sladjana Samuilov ${ }^{1 *}$, Nadine Rademacher ${ }^{2}$, Dominik Brilhaus ${ }^{2}$, Samantha Flachbart ${ }^{2}$, \\ Leila Arab ${ }^{1}$, Stanislav Kopriva ${ }^{3}$, Andreas P. M. Weber ${ }^{2}$, Tabea Mettler-Altmann ${ }^{2}$ and \\ Heinz Rennenberg ${ }^{1,4}$ \\ ${ }^{1}$ Chair of Tree Physiology, Institute of Forest Sciences, Faculty of Environment and Natural Resources, University of Freiburg, \\ Freiburg, Germany, ${ }^{2}$ Institute of Plant Biochemistry, Cluster of Excellence on Plant Sciences, Heinrich Heine University, \\ Düsseldorf, Germany, ${ }^{3}$ Botanical Institute, Cluster of Excellence on Plant Sciences, University of Cologne, Cologne, \\ Germany, ${ }^{4}$ College of Science, King Saud University, Riyadh, Saudi Arabia
}

Keywords: amino acids, Cd treatment, cysteine, glutathione, glycine, phosphorylated pathway, serine

\section{OPEN ACCESS}

Edited and reviewed by:

Jean-Philippe Reichheld, Centre National de la Recherche

Scientifique (CNRS), France

${ }^{*}$ Correspondence:

Sladjana Samuilov

sladjana.samuilov@ctp.uni-freiburg.de

Specialty section:

This article was submitted to

Plant Physiology,

a section of the journal

Frontiers in Plant Science

Received: 20 February 2019

Accepted: 28 February 2019

Published: 26 March 2019

Citation:

Samuilov S, Rademacher N,

Brilhaus D, Flachbart S, Arab L

Kopriva S, Weber APM,

Mettler-Altmann $\mathrm{T}$ and Rennenberg $\mathrm{H}$

(2019) Corrigendum: Knock-Down of

the Phosphoserine Phosphatase

Gene Effects Rather N-Than

S-Metabolism in Arabidopsis thaliana.

Front. Plant Sci. 10:325

doi: 10.3389/fpls.2019.00325

\section{A Corrigendum on}

Knock-Down of the Phosphoserine Phosphatase Gene Effects Rather N- Than S-Metabolism in Arabidopsis thaliana

by Samuilov, S., Rademacher, N., Brilhaus, D., Flachbart, S., Arab, L., Kopriva, S., et al. (2018). Front. Plant Sci. 9:1830. doi: 10.3389/fpls.2018.01830

In the original article, there was a mistake in Figure 6 as published. On the $y$-axis " $\mathrm{nmol} \mathrm{g}^{-1}$ FW" was used instead of " $\mu \mathrm{mol} \mathrm{g}{ }^{-1} \mathrm{FW}$ " for the total NPT content measurement. The corrected Figure 6 appears below.

A correction has been made to the Materials and Methods, subsection Quantification of Total Non-Protein Thiols:

"For the determination of total non-protein thiols (NPT), a modified method of Queval and Noctor (2007) was applied. Total thiols in leaf extract were assayed as 5,5'-dithio-bis-[2nitrobenzoic acid]-reactive thiols (DTNB-reactive thiols) by spectrophotometry (Beckman UVDU650, Beckman Coulter, United States) using glutathione (GSH) as a standard. Approximately $100 \mathrm{mg}$ frozen leaf powder was extracted in $1 \mathrm{ml} 0.2 \mathrm{~N} \mathrm{HCl}$. Aliquots of $0.5 \mathrm{ml}$ supernatant were transferred into fresh micro tubes (Sarstedt AG \& Co., Nümbrecht, Germany) and neutralized with $0.4 \mathrm{ml} 0.2 \mathrm{M} \mathrm{NaOH}$ in the presence of $50 \mu \mathrm{l} 0.2 \mathrm{M} \mathrm{NaH}_{2} \mathrm{PO}_{4}(\mathrm{pH}$ 5.6). For thiol quantification by spectrophotometry, each semi-micro cuvette (Sarstedt AG \& Co., Nümbrecht, Germany) contained $500 \mu \mathrm{l}$ phosphate-EDTA buffer $\left(0.2 \mathrm{M} \mathrm{NaH}_{2} \mathrm{PO}_{4}, \mathrm{pH} 7.5 ; 10 \mathrm{mM}\right.$ EDTA $), 50 \mu \mathrm{l}$ of $12 \mathrm{mM}$ DTNB and $450 \mu \mathrm{l}$ neutralized sample extract (total volume $1 \mathrm{ml}$ ). For standards, the extract was replaced by $450 \mathrm{ml}$ of $0,10,20,30,40,50 \mu \mathrm{mol} \mathrm{GSH}$. The absorbance was measured at a wavelength of $412 \mathrm{~nm} 3 \mathrm{~min}$ after addition of extract or standard."

The authors apologize for these errors and state that they do not change the scientific conclusions of the article in any way. The original article has been updated. 


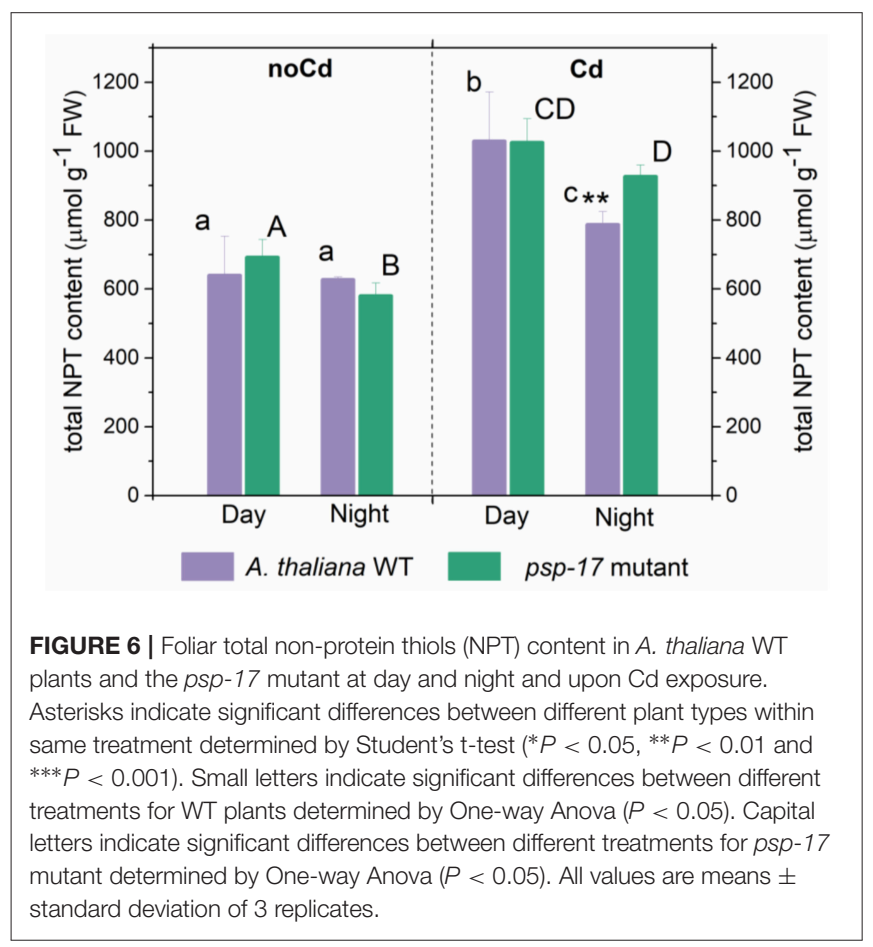

\section{REFERENCES}

Queval, G., and Noctor, G. (2007). A plate reader method for the measurement of NAD, NADP, glutathione, and ascorbate in tissue extracts: application to redox profiling during Arabidopsis rosette development. Anal. Biochem. 363, 58-69. doi: 10.1016/j.ab.2007.01.005

Copyright (c) 2019 Samuilov, Rademacher, Brilhaus, Flachbart, Arab, Kopriva, Weber, Mettler-Altmann and Rennenberg. This is an open-access article distributed under the terms of the Creative Commons Attribution License (CC BY). The use, distribution or reproduction in other forums is permitted, provided the original author(s) and the copyright owner(s) are credited and that the original publication in this journal is cited, in accordance with accepted academic practice. No use, distribution or reproduction is permitted which does not comply with these terms. 